\title{
OPTIMIZATION OF MAIN PARAMETERS OF TRACTOR AND UNIT FOR SEEDING CEREAL CROPS WITH REGARDS TO THEIR IMPACT ON CROP PRODUCTIVITY
}

\author{
Ramil Khafizov, Camill Khafizov, Azat Nurmiev, Ilgiz Galiev \\ Kazan State Agrarian University, Russia \\ ramilajz@mail.ru,fts-kgau@mail.ru, azat-nurmiev@mail.ru,drgali@mail.ru
}

\begin{abstract}
The article determines the weight and power of the tractor, as well as the width of the seeder and the operational speed of the tractor-seeder unit based on the new method. Using multi-cycle, multi-parameter calculations, it is revealed that the seeding operation quality could be achieved with a single combination of optimal values of the tractor weight and power, which are almost the same even within different environmental conditions. The main influence on the optimal value of the tractor weight and engine power is caused by a specific traction resistance of the seeder. For the seeder specific traction resistances ranging from 3.2 to $5.2 \mathrm{kN} \cdot \mathrm{m}^{-1}$, the optimal value of the tractor weight for seeding operations with a DMC-implement (chisel-shaped openers) is in the range from 80 to $120 \mathrm{kN}$. The required rational power varies from $200 \mathrm{hp}$ up to $310 \mathrm{hp}$. The optimal seeder width is $12 \mathrm{~m}$, the optimum speed of the unit is $12 \mathrm{~km} \cdot \mathrm{h}^{-1}$. The nomograph is proposed for seeders with a different working width, with a different type of working elements and, accordingly, with a different traction resistance. The optimum values of the main parameters of the tractor revealed by the proposed graph will ensure minimum total energy costs for seeding, by reducing the energy costs of the lost crop. Increasing the operational speed of the seeding units leads to an increase in required power of the tractor engine, while maintaining the value of its weight.
\end{abstract}

Key words: tractor, weight, power, optimization, total energy costs, mathematical model, seeder.

\section{Introduction}

The considerable attention in foreign and domestic scientific literature is paid to increase in the efficiency of use of tractors and tractor-implement units. For assessment of the efficiency of tractors and units different indicators are used - productivity, fuel usage on 1 hectare, given expenses and other indicators [1-5]. These indicators do not consider the influence of parameters of the equipment (technology) on the created harvest. Therefore, scientists pay considerable attention to studying of interaction of a running gear of tractors with the soil and to influence of soil compaction on the created harvest [6-15]. Operating conditions of tractors and their influence on the indicators of efficiency are investigated [16; 17]. There is a need of a system approach for justification of the parameters of tractors taking into account their influence on the created harvest.

On the basis of many years of research, we developed a system mathematical model of atractor and an implement has been developed using the energy optimization criterion - total energy costs. Numerous pilot studies proved adequacy of the mathematical model of different tractor-implement units [18-20]. Total energy costs, in addition to direct and indirect energy costs, include the energy of the crop lost due to incorrectly selected parameters and operating modes of implements, which occupies from 40 to $80 \%$ of the total energy costs in various operations and operating conditions of implements [19-21]. The model allows, based on the use of numerical methods of calculation, to identify the optimal basic parameters of the tractor (weight of the tractor and the power of its engine) while simultaneously revealing the optimal width of the implement and its working speed. This article deals with a technological operation carried out with seeders from different manufacturers, differing in the design of the working bodies.

\section{Materials and methods}

The study to identify the optimal basic parameters of the tractor during sowing is carried out on the basis of computational experiments using the energy-based system mathematical model of sowing implements (seeders). Calculations are carried out using Matlab computer mathematics system using code developed in [22].

\section{Results and discussion}

With the use of the developed energy-based mathematical model of sowing implements, computational experiments were carried out to identify the optimal basic parameters of the tractor 
operating in the unit with seeders from different manufacturers and having different working bodies (single-disk, double-disk, cultivator, chisel, anchor).

The results of optimization of the main parameters of the tractor and DMC seeding complex with chisel-shaped opener for the most common operating conditions of these implements - field area of 100 hectares, specific resistance of the soil to the working organs of the seeder $4 \mathrm{kN} \cdot \mathrm{m}^{-1}$, work volume 1000 ha are shown in Fig. 1.

The input data for the calculation with seeding complex DMC:.

- $\quad$ single field area, ha = 100;

- length of the unit run before turn, $\mathrm{km}=1$;

- moving distance from field to field, $\mathrm{km}=3$

- $\quad$ seeds density, $\mathrm{kg} \cdot \mathrm{m}^{-3}=800$;

- bearing surface strength coefficient $=1$;

- $\quad$ scope of work, ha $=1000$;

- number of tractors used for technological operation $=1$;

- $\quad$ working hours a day $=14$;

- planned productivity of main and by-products, $\mathrm{c} \cdot \mathrm{ha}^{-1}$. [centner per hectare] $=40$;

- pressure in the tires (from 0.08 to 0.2 ), $\mathrm{MPa}=0.16$;

- $\quad$ number of wheels on one side of the tractor $(1$ or 2 or 3 , etc. $)=1$;

- coefficient of traction of wheels with soil $=0.6$;

- $\quad$ coefficient of resistance to rolling of tractor wheels $=0.16$;

- $\quad$ coefficient of distribution of coupling weight of wheels $=0.9$.

Calculation results:

- $\quad$ width of implement $B_{\text {opt }}=12 \mathrm{~m}$;

- $\quad$ working speed $V_{\text {opt }}=12 \mathrm{~km} \cdot \mathrm{h}^{-1}$;

- weight of the tractor $G_{\text {tiopt }}=97 \mathrm{kN}$;

- engine power $N_{\text {eopt }}=254.04 \mathrm{hp}$;

- total energy consumption $E_{\min }=10524 \mathrm{MJ} \cdot \mathrm{ha}^{-1}$

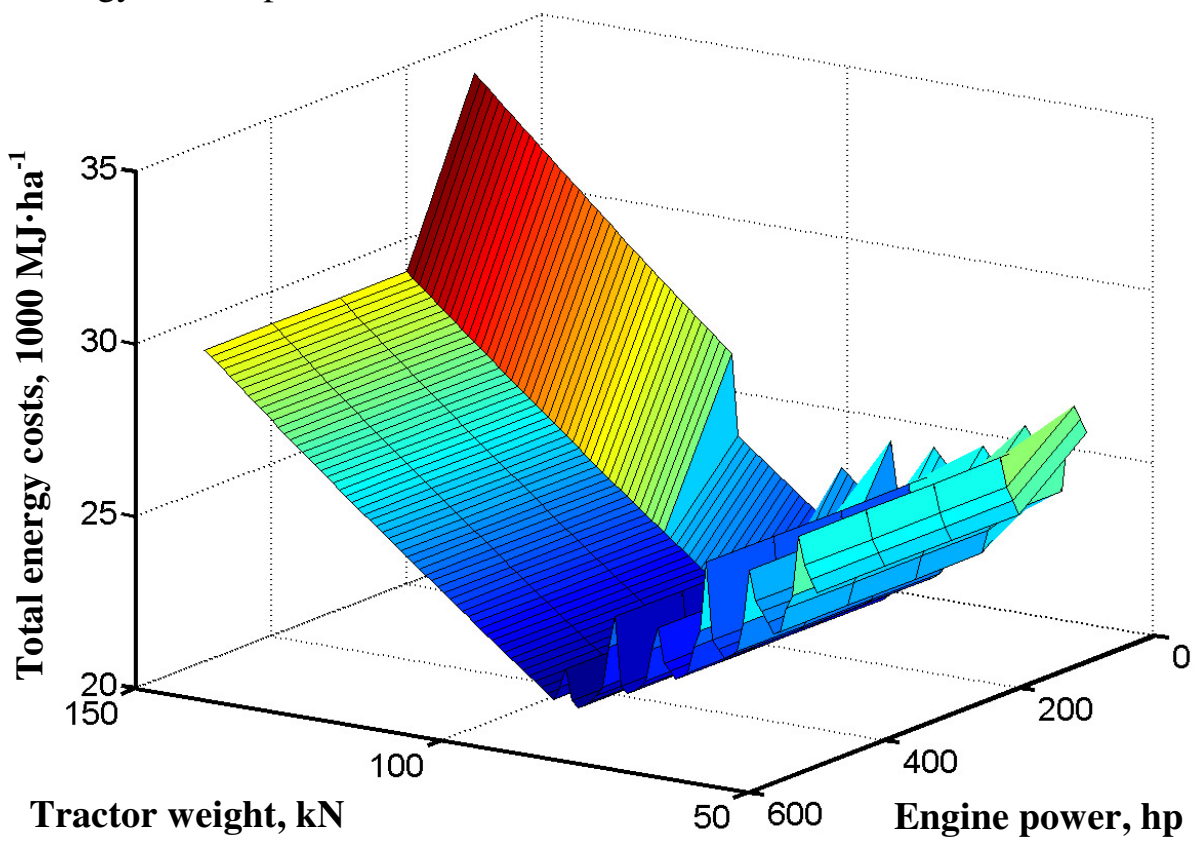

Fig. 1. Change in total energy costs depending on ratio of weight and power of tractor engine

It is seen in the figure that there is an optimal combination of the weight of the tractor and the power of its engine (with the appropriate optimum values of speed and width of the seed unit).

We performed computational experiments to identify the influence of some factors on the main parameters of the tractor. 
Fig. 2 shows the calculated data on the effect of changing the pressure in the tire wheels of the tractor on the optimal parameters of the tractor working with a DMC seeder with chisel-type coulter. Optimal values of the main parameters of the tractor, as can be seen from the figure, are: the weight is near to $97 \mathrm{kN}$, and the required power of the tractor engine is within $254 \mathrm{hp}$. The optimum width of the implement to work with the tractor is $12 \mathrm{~m}$. The total energy costs with low intensity increase in the tyre pressure are steadily growing.

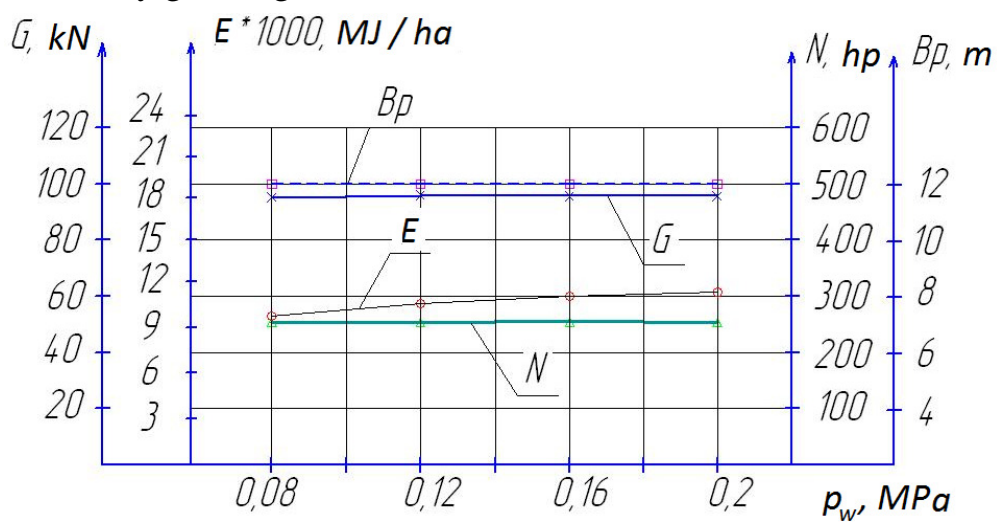

Fig. 2. Effect of tractor tire pressure changes on optimal values of main parameters of seeding implement with sowing complex DMC and its total energy consumption

As it can be seen from Fig. 3, there is some change in the optimal weight of the tractor and the power of its engine due to seasonal load on the unit, especially with its growth from 500 to 750 ha.

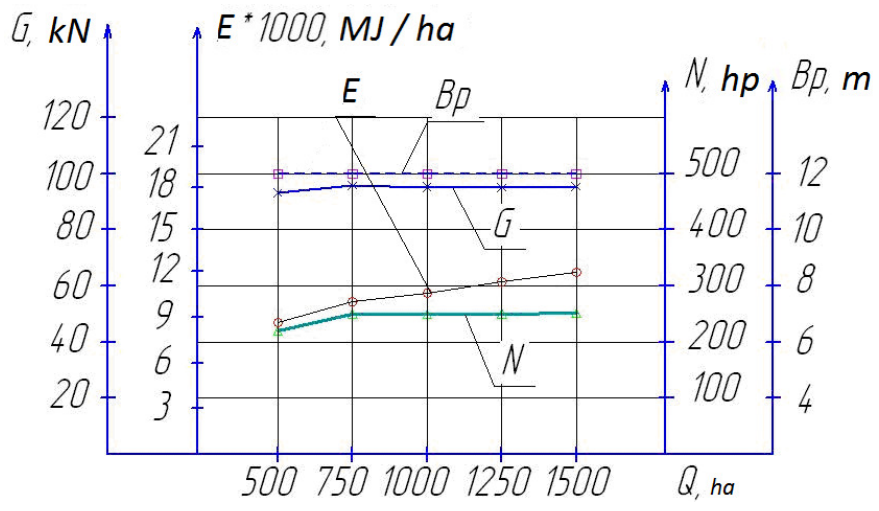

Fig. 3. Effect of unit seasonal load (in hectares) on optimal values of main parameters of seeding implement with sowing complex DMC and its total energy consumption

The weight of the tractor increased from 95 to $97 \mathrm{kN}$, while the optimum engine power required increased from 207 to $254 \mathrm{hp}$. The optimal value of the implement width is kept equal to $12 \mathrm{~m}$. The total energy costs with the growth of the seasonal load are steadily increasing.

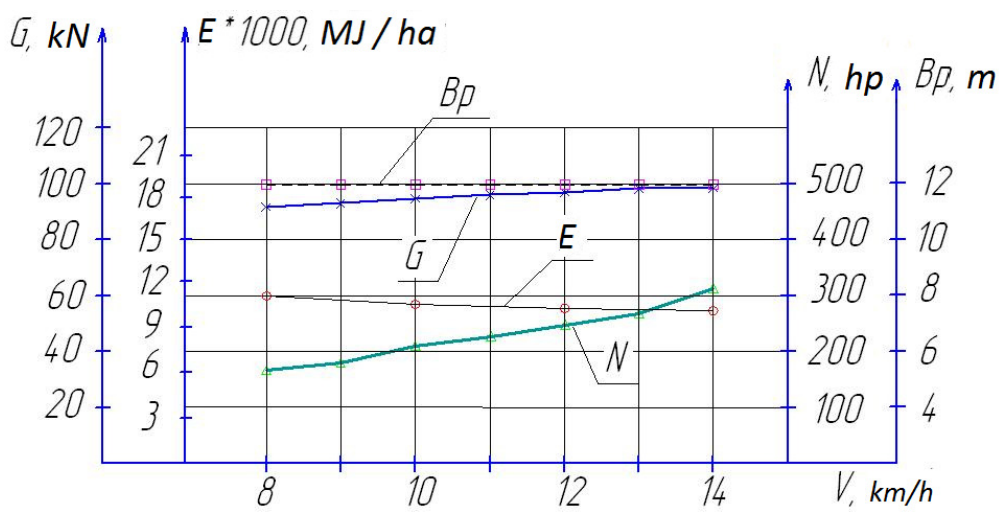

Fig. 4. Effect of change in unit speed on optimal values of main parameters of seeding implement with sowing complex DMC and its total energy consumption 
As per data shown in Fig.4, ranging the speed of the unit from 8 to $14 \mathrm{~km} \cdot \mathrm{h}^{-1}$ changes accordingly the optimal weight of the tractor from 93 to $99 \mathrm{kN}$, the required power increases from $162 \mathrm{hp}$ up to $303 \mathrm{hp}$ The optimal implement width is $12 \mathrm{~m}$, and the total energy consumption decreases with the speed from $11395 \mathrm{MJ} \cdot \mathrm{ha}^{-1}$ to $10355 \mathrm{MJ} \cdot \mathrm{ha}^{-1}$.

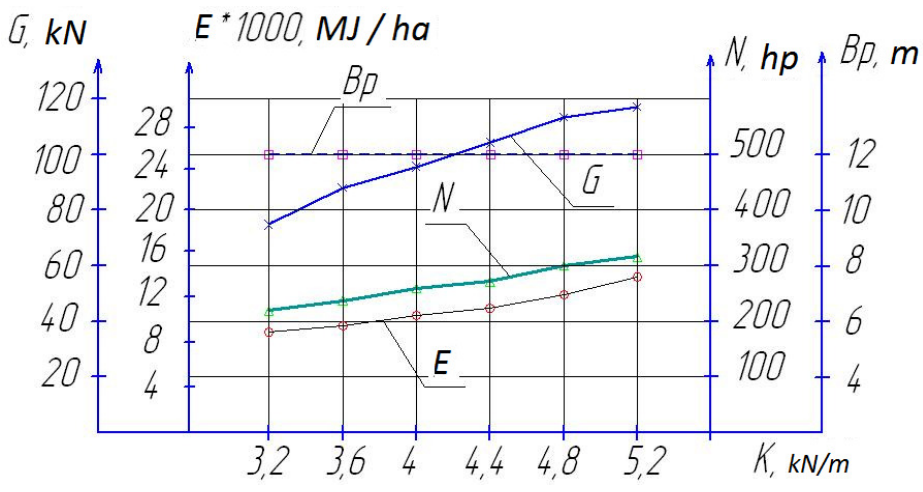

Fig .5. Effect of changes in soil resistivity on optimal values of main parameters of seeding implement (DMC seeding complex) and its total energy consumption

From Fig. 5 it can be seen that with increasing the soil resistance from 3.2 to $5.2 \mathrm{kN} \cdot \mathrm{m}^{-1}$, the optimal weight of the tractor is increasing from $78 \mathrm{kN}$ to $118 \mathrm{kN}$, and its engine power from 200 to $305 \mathrm{hp}$.

The optimal value of the implement width of the unit remains unchanged, equal to $12 \mathrm{~m}$, while the speed of the unit is $12 \mathrm{~km} \cdot \mathrm{h}^{-1}$.

Thus, the optimal values of the main parameters of the tractor for seeding with the DMC seeding are in the range from 80 to $120 \mathrm{kN}$, the required power ranges from 200 to $310 \mathrm{hp}$. The optimum width of the implement is $12 \mathrm{~m}$.

The same calculations were performed for seeding units with other types of working bodies. After a generalization of all calculated data and analysis performed, it became possible to construct the nomograph shown in Fig. 6, establishing dependencies between the parameters of the tractor and the seeding implement, depending on the specific traction resistance of the seeder.

The research carried out revealed that when sowing grain (cereal) crops, there is an optimal combination of the weight of the tractor and the power of its engine. Computational experiments made it possible to establish that the optimum values of the main parameters of the tractor remain stable, when the pressure in the tires of the tractor changes the seasonal load on the unit as important factors that affect the loss of the crop yield of cereals. Increasing the working speed of the seeding unit leads to a reduction in total energy costs, but requires an increase in the power of the tractor engine with a relative constant weight of the tractor. The greatest influence on the weight of the tractor and the power of its engine is the resistance of the soil to the working parts of the seeding unit. With increasing the soil resistance, the required optimal weight of the tractor and the power of its engine are steadily increasing. Total energy costs, with increasing resistance of the soil to the working bodies, are increasing.

The nomograph given in Fig. 6 makes it possible to determine the optimal weight of the tractor depending on the specific resistance of the soil to the working bodies of the seeders and the width of the used seeder and, subsequently, the required optimum power of the tractor engine, depending on the working speed of the unit. The nomograph is applicable not only to drills with working elements in the form of a chisel, but also with other types of working bodies - single-disk, double-disk, anchor and lancet paws-formed openers. Knowing the specific resistance of the soil to the working bodies of the seeder, the width of the seeder could be found on the nomograph and for it the weight of the tractor determined. The greater the width of the drill, the lower the total energy costs, so for fields larger than 20 hectares (see the rationale in Fig. 7), it is better to select the seeder with the maximum possible width. Knowing the weight of the tractor, power of its engine could be determined, using given speed of the unit. It should be noted that the greater the speed of the unit, the lower the total energy costs (of course, within the technological requirements, which ensure operation quality), but this will require an increase in the engine power. 


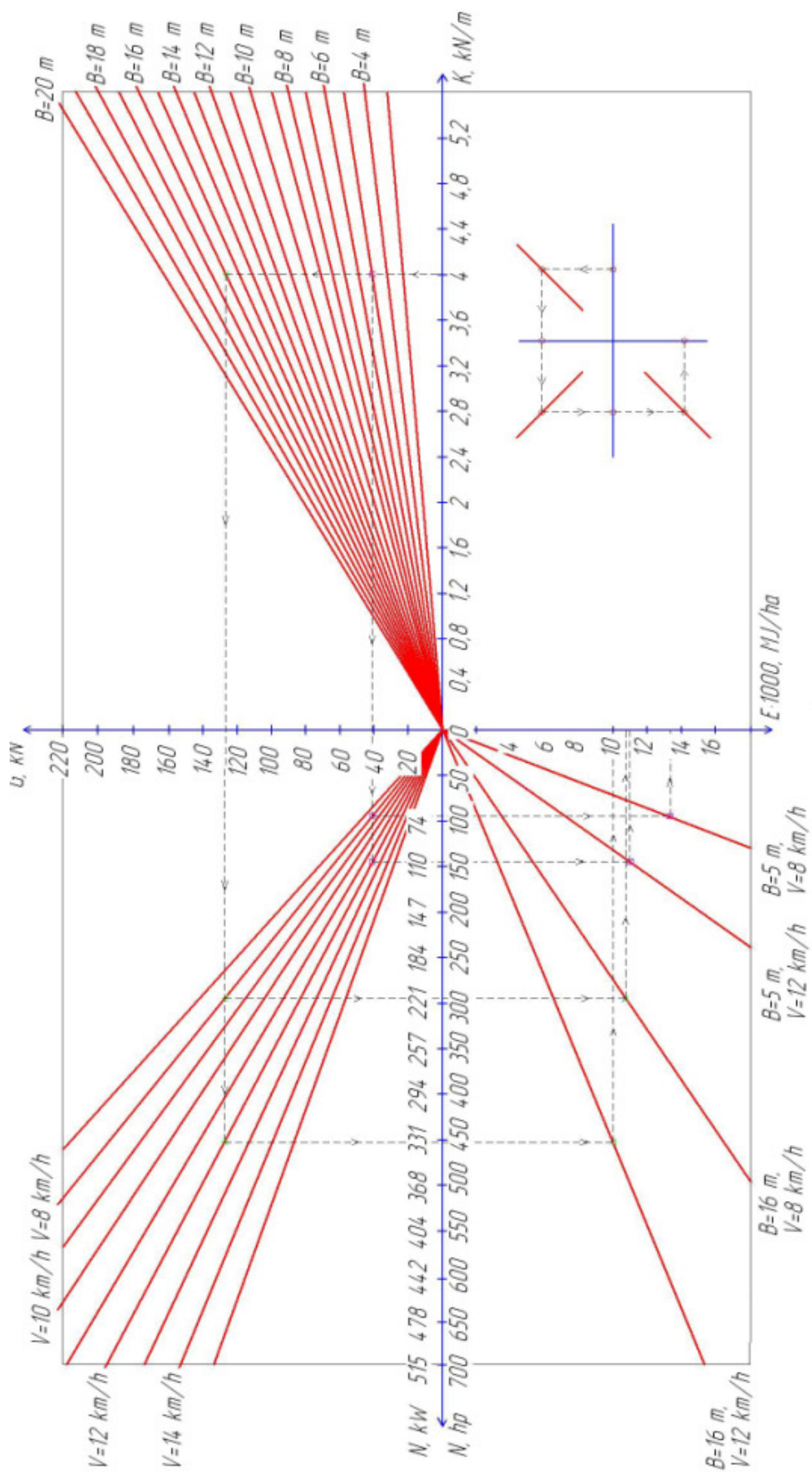

Fig. 6. Nomograph to determine optimal weight of tractor and power of its engine, depending on specific soil resistance, width of unit and its speed 


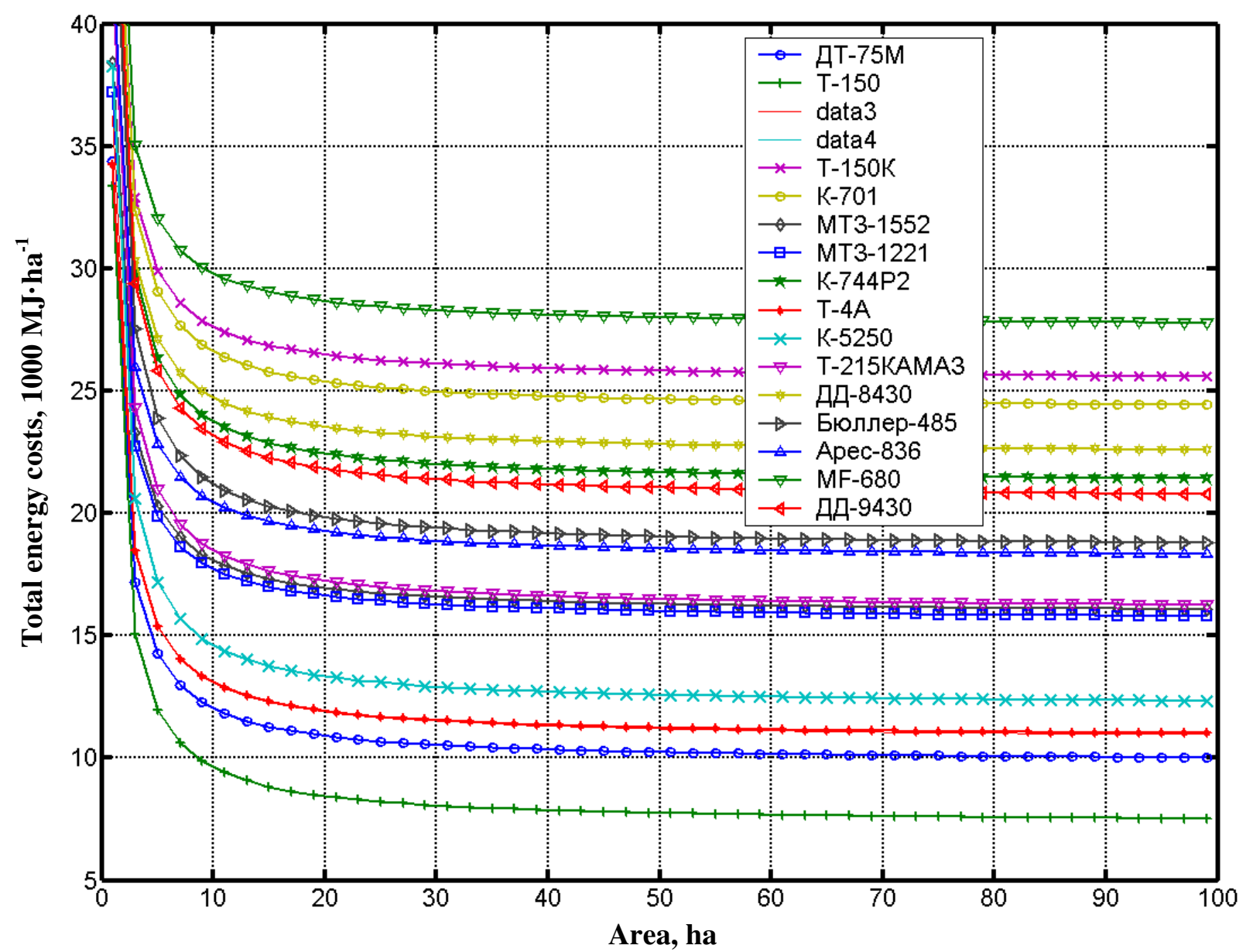

Fig. 7. Change in total energy costs of sowing units compiled on basis of existing tractors

\section{Conclusions}

1. In the range of soil resistivity to the working bodies of the seeder from 3.2 to $5.2 \mathrm{kN} \cdot \mathrm{m}^{-1}$, the optimum value of the tractor weight for seeding operations with a DMC seeding complex (chiselshaped openers) is in the range from 80 to $120 \mathrm{kN}$, depending on the operating conditions. The required rational power varies from $200 \mathrm{hp}$. up to $310 \mathrm{hp}$. The optimal width of the implement is $12 \mathrm{~m}$, the optimum speed of the unit is $12 \mathrm{~km} \cdot \mathrm{h}^{-1}$.

2. If a manufacturer proposes agricultural implements, seeders with a different working width, with a different type of working bodies and, correspondingly, with a different soil resistance to the working bodies, it is necessary to use the nomograph shown in Fig. 6 . The optimum values of the main parameters of the tractor revealed by it will ensure minimum total energy costs for sowing, and minimum loss of a harvest.

3. The materials of this article can be useful for the farmers and owners of agricultural machinery in order to justify the selection of the main parameters of the tractor and sowing units; for the designers of tractors, for students of agrarian higher education institutions specified in agricultural engineering trainings and studies; for teachers and scientists, who do work in design and operation of tractors and tractor and implement units.

\section{References}

[1] Adsit A.H., Clark R.L. Tractive and energy performance of a small four-wheel drive tractor. ASAE Paper No. 81-1042, ASAE, St. Joseph, MI 49085, 1981.

[2] Upadhyaya S.K., Ma T.X., Chancellor W.J., Zhao Y.M. Dynamics of soil-tool interaction Soil Tillage Res., 9 (1987), pp. 187-206. 
[3] Scarlett A. J. Integrated control of agricultural tractors and implements: review of potential opportunities relating to cultivation and crop establishment. Computers and Electronics in Agriculture, 30: 2001, pp. 167-191.

[4] Stombaugh T. S., Benson E. R., Hummel J. W. Guidance control of agricultural vehicles at high field speeds. Transactions of ASAE, 42(2), 1999, pp. 537-544.

[5] Givan W., Hammond C. Selection of Farm Tractors. Cooperative Extension Service. University of Georgia College of Agriculture. Athens, GA. Miscellaneous Publication Number 68, 1978.

[6] Ansorge D., Godwin R.J. The effect of tires and a rubber track at high axle loads on soil compaction - Part 1: Single axle-studies. Biosyst. Eng. 98, 2007, pp. 115-126.

[7] Ansorge D., Godwin R.J. The effect of tires and a rubber track at high axle loads on soil compaction - Part 2: Multi-axle machine studies. Biosyst. Eng. 99, 2008, pp. 338-347.

[8] Ansorge D., Godwin R.J. The effect of tires and a rubber track at high axle loads on soil compaction - Part 3: Comparison of virgin compression line approaches. Biosyst. Eng. 104, 2009, pp. 278-287.

[9] Arvidsson J., Westlin H., Keller T., Gilbertsson M. Rubber track systems for conventional tractors - Effects on soil compaction and traction. Soil Till. Res. 117:, 2011, pp. 103-109.

[10]Batey T. Soil compaction and soil management - a review. Soil Use Manage. 25, 2009, pp. 335-345.

[11] Chamen W.C., Moxey A.P., Towers W., Balana B., Hallett P.D. Mitigating arable soil compaction: review and analysis of available cost and benefit data. Soil Till. Res. 146, Part A, 2015, pp. 10-25.

[12] Håkansson I., Reeder R.C. Subsoil compaction by vehicles with high axle load-extent, persistence and crop response. Soil Till. Res. 29, 1994, pp. 277-304.

[13] Schjønning P., Lamandé M., Tøgersen F.A., Arvidsson J., Keller T. Modelling effects of tire inflation pressure on the stress distribution near the soil-tire interface. Biosyst. Eng. 99, 2008, pp. 119-133.

[14] ASAE, St Joseph, Mi, USA. Reid J.T. A comparison of the energy input of some tillage tools. ASAE Paper 78-1039, 1978.

[15] John Deere Road, Moline, Illinois, 61265, USA. He, C.S.; Lui X. L., Zhang D. J., Yang X.W. (1989). Methodological research on agricultural machinery selection. Proceedings of the internation al symposium on agricultural engineering (89 - ISAE) Beijing China 12 - 15 September, 1989, pp. 118-121.

[16]Галиев И.Г., Хусаинов Р.К. Оценка условий функционирования в сельскохозяйственном производстве (Assessment of operating conditions in farm-production), The machinery and equipment for the village: Техника и оборудование для села. 2015. - № 10. - С. 13 - 15. (in Russian)

[17]Галиев И.Г., Хусаинов Р.К. Определение перечня факторов характеризующих условия эксплуатации тракторов (Definition of the list of factors of the tractors characterizing operating conditions), ), Bulletin of Kazan State Agrarian University: Вестник Казанского государственного аграрного университета. - Казань, 2015. - № 3. - С. 77 - 88. (in Russian)

[18] Хафизов К.А. Оптимизация параметров и режимов работы машинно-тракторных агрегатов на основе энергетического анализа (Optimization of parameters and operating modes of tractorimplement units based on energy analysis), Tractors and agricultural machinery: Тракторы и сельхозмашины, 2006, No.7, pp. 7-9. (in Russian)

[19]Хафизов К.А. Пути снижения энергетических затрат на производственных процессах в сельском хозяйстве (Ways to reduce energy costs in production processes in agriculture). Kazan: Kazan State University Press, 2007. - 272 p. (in Russian)

[20]Хафизов Р.Н., Хафизов К.А. Повышение эффективности использования тракторов (Increasing epy efficiency tractors usage), Mechanization and electrification of agriculture: Механизация и электрификация сельского хозяйства, 2010, No.12, pp. 14 - 15. (in Russian)

[21]Хафизов Р.Н., Хафизов К.А. Обоснование пределов изучаемой системы - машиннотракторный агрегат на посеве и выбор критерия оптимизации параметров тракторов (justification of limits of tractor-implement system under studied for seeding operation and choosing tractor optimization criteria), Conference materials: «Научное сопровождение агропромышленного комплекса: теория, практика, перспективы» Материалы 
международной научно-практической конференции, посвященной 65-летию образования Института механизации и технического сервиса, Kazan: Published by Kazan State Agrarian University, 2015, pp. 421 - 426. (in Russian)

[22] Хафизов К.А., Хафизов Р.Н. Программа оптимизации основных параметров трактора для выполнения комплекса операций (Program for optimization of the main parameters of the tractor for performing a complex of operations) // Свидетельство о государственной регистрации программ для ЭВМ (Computing program registration certificate), No.2016611126, 30.11.2015. 